\title{
Inhaled steroids: First line treatment of adult asthma
}

\author{
ANDRÉ CARTIER MD FRCPC \\ Chest Department, Sacré-Coeur Hospital, Montreal, Quebec
}

\begin{abstract}
A CARTIER. Inhaled steroids: First line treatment of adult asthma. Can Respir J 1995;2(Suppl A):10A-12A.
\end{abstract}

Corticosteroids are the most potent inhaled anti-inflammatory drugs for asthma treatment. This paper reviews the clinical evidence supporting the early use of inhaled steroids in asthma as a first line treatment. Inhaled steroids (an probably alter the course of asthma, especially in mild asthmatics. Once they have been shown to improve control of asthma and even if the need for beta2-agonists is virtually nil, their use should be continued at low doses (ie, equivalent to 400 to $500 \mu \mathrm{g}$ of budesonide or beclomethasone) for at lealst onc year before attempting to reduce the dosage.

Key Words: Asthma. Inhated steroids. Prephingatis

\section{Corticosteroïdes inhalés: traitement de première ligne dans l'asthme}

RÉSUMÉ : Les corticostérö̈des sont les agents antiinflammatoires inhalés les plus puissants que nous possédons pour le traitement de l'asthme. Dans cet article, l'auteur revoit les données cliniques qui supportent l'utilisation de stéroïdes inhalés comme médication de première ligne dans le traitement de l'asthme. Ces demiers peuvent probablement altérer l'évolution de l'asthme particulièrement chez l'asthmatique léger. Une fois qu'on a documenté leur efficacité et même si le besoin en beta2-agonistes esı virtuellement nul, l'auteur propose de les continuer à faible dose, soit l'équivalent de 400-500 $\mu \mathrm{g}$ de budésonide ou béclométhasone, pour au moins un an avant de tenter (l'cu réduire la posologie.
$\mathrm{O}$ VER THI: PAST FEW YEARS, MANY STUDIES HAVE HIGHighted the primary rok of bronchial inflammation in the pathophysiology of asthmia. While hronchodilators had been considered in the past as the main treatment of asthma, the emphasis is now on the control of inflammation in order to decrease airwaly obstruction and improve bronchial responsiveness.

To reduce airway inflammation and improve asthmat control, the first step is envirommental control such as elimination of relevant allergens and irritants such ats cigarette smoke. However, this is usually not sufficient and the subject may reyuire anti-inflammatory drugs, primarily steroids and secondarily sodium cromoglycate or nedocronil sodium. The aim of this paper is lo evaluate the role of inhaled steroids as first line treatment in the control of asthma in adults.

\section{CANADIAN AND INTERNATIONAL GUIDELINES}

The present Canadian guidelines, driwn from two consensus meetings held in May and October 1989, were published by Hargreave et al in $1990(1.2)$. Asthmat control is defined by mininal (ideally none) airway obstruction and symptoms (ideally none) with little use of inhaled beta2-agonists. According to these guidelines, an adult asthmatic requiring as sole medication an inhaled beta2-agonist twice a day or less is considered to be well controlled (level 1). However, in the adult who requires a beta2-agonist more than twice but fewer than four times a day, is not awakened at night with asthma, and has normal spironetry, low close inhaled steroids. equivalent to 400 to 500$) \mu \mathrm{g}$ per day of budesonide or becilomethasone, is recommended (level 2). Higher doses of in.haled steroids are given to those subjects who are more symptomatic, and additionat necdication may be added such at nedocromil, ipratropium bromide, theophylline and oral long-acting beta2-agonist (level 3). At the time these guidelines were prepared, inhaled long-acting beta2-agonists such as salmeterol and fomoterol were not available.

According to more recent international guidelines (3-5), asthma is not controlled if an asthmatic requires an inhaled beta2-agonist datly. and cven at this early stage low dose

Correspondence: Dr. André Cartier. Service de pneumologie-recherche. Hôpital du Sacré-Cre'tr' "k' Montréal. 5400 , houlevard Gouin

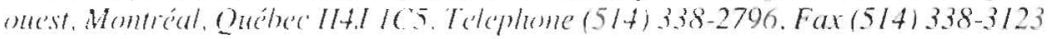


inhaled steroids are suggested. The same guidelines, however, suggest that cromoglycate or nedocromil may be used instead of steroids. Canadian and international guidelines thus differ in their definition of asthma control in terms of the maximum doses of betaz-agonists needed before low dose inhaled steroids are introduced. This is atso reflected in the daily practice of Canatian physicians, with some giving inhaled steroids carlier than others. This difference in prescription is likely to be related to the fear of the side effects of inhaled steroids; if they are used prophylatctically (ie, to abolish symptoms and betaz-agonist use), they should not induce more side effects than benefits. To answer this dilemma, we must deternine in adults on the one hand the safe daily dose and on the other the minimal effective dose.

\section{IS THERE A SAFE DAILY DOSE OF INHALED STEROIDS?}

The adverse effects of inhaled stcroids are related to their local action and their systemic absorption (6). At an equivatIent therapeutic dose. inhaled steroids have much fewer systemic side effects than oral steroids but as the dosage is increased, the absorption and thus the risk of significant adverse effects is increased. Locally, hoarseness and oral pharyngeal candidiasis are the most frequent side effects; the frequency of these effects is dosc-dependent and is effectively diminished by the use of a spacer device for the metered-dose inhaler (MDI) (7) or by rinsing the throat for the Turbuhaler. Cough and bronchospasm arc much less frequent adverse effects.

Toogood (6) recently published a revicw of the adverse side effects associated with the systemic absorption of inhaled steroids. The effect of the hypothalamo-pituitary-adrenal axis. with diminished plasma or urinaty cortisol, is seen at a dose usually higher than $150(0) \mathrm{lg} / \mathrm{daty}$ of beclomethasone or its equivalent, but af few subjects taking a lower dose, such as 600 to $1000 \mu g /$ day. maty exhibil abnomal findings. Even if these biochemical changes have not been associated with any clinical matnifestations, except in one odd case (8), they must be taken into consideration when prescribing inhaled steroids for prophylaxis. The use of spacer devices with the MDI or throal rinsing with the Turbuhaler effectively reduces systemic absorption $(9,10)$. An effect on bone metabolism has not been documented at doses lower that $1(0)(0) \mu \mathrm{g} /$ daty, although diminution of serum osteoculcin has been observed in some subjects taking doses of $1000 \mu \mathrm{g} /$ day. There is no effect on glucose metabolism but chatnges in plasma cholesterol and required insulin dosage arc controversial. There is no evidence of a higher incidence of cataracts in association with inhaled steroids (11). IFinally, physicians are aware of easy bruising assoctated with high doses of inhaled steroids (12), but at doses lower than 800 to $l(k)() \mathrm{lg} /$ day this complication is rare.

Therefore, in adults we may consider doses of inhaled stcroids equivalent to $4(0)$ 10 50() $\mathrm{\mu g} /$ day of budesonide or beclomethasone to be clearly salte, as there is no evidence of any systemic absorption or potentially serious adverse effects. It is less clear, however. whether doses between 500 and $1000 \mu \mathrm{g} /$ day are as safe for all patients.

\section{IS THERE A MINIMAL EFFECTIVE DOSE?}

It is well established that inhaled steroids at low doses can improve the control of asthma in most subjects (13, I4). Furthermore, early introduction of inhaled steroids in asthma seems justified in view of the recent studies of Agertoft et al (15) in children and of Haahtela et al (16) in adults. Both these studics showed that those asthmatics who are griven inhaled steroids early have a better outcome in terms of arrvaly function in comparison with those who receive inhaled steroids at similar doses but at al later stage. In addition. the availability of inhaled steroids at high concentration, such as beclomethasone at $250 \mu \mathrm{g} /$ dose or budesonide att 200 or $400 \mu \mathrm{g} /$ dose, allows physicians to give low dose stcroids once or twice a day, thus improving patient compliance greatly.

Keeping in mind the upper safe limit of 500$) \mathrm{ug} / \mathrm{daly}$ of inhaled steroids, we will only comsider subjects who are ivell controlled with this low dose. Juniper et al (13) hatve shown in a double-blind placebo controlled study that budesonick $200 \mu \mathrm{g}$ bid can markedly improve asthma control in symptomatic subjects requiring bronchodilators regularly. Indeed, apart from reducing symptoms and the need for rescue bronchodilators, budesonide was associated with a significant reduction of nonallergic bronchial responsiveness not seen with placebo. This one-year study showed that the improvement in nonallergenic bronchial responsiveness and in symptoms reached a plateau after six months. More interestingly, some subjects on budesonide became completely asymptomatic during the study period, requiring no more bronchodilators and normalizing their bronchial response to methacholine and exercist.

In theory, if one had followed the Canadian or international guidelines, inhaled steroids shoukl have been reduced and even stopped as patients became symptomatic. I lowever. studies on the effect of inhaled steroids on nonallergic bronchial responsiveness have clearly demonstrated that short term administration (up to 10 weeks) of inhaled steroids is associated with only at transient improvement in bronchial responsiveness and symptoms (17-19). However. Juniper et al (20) have shown that budesonide $200 \mu \mathrm{g}$ bid given for onc year leads to a more prolonged improvement of symptoms and nonallergic bronchial responsiveness, even after it has stopped; sonk subjects sitw a recurrence of their synıtoms (mainly cough) after three months of cessation of budesonide. Furthermore, Osterman et al (2l) have shown that $50 \%$ of subjects who had received budesonide for one year maintained their improvement in bronchial responsiveness six months alfer cessittion of budesonide. Also, Halihtela et al (16) showed thitt a higher dose of budesonide (1200) $\mu \mathrm{d} / \mathrm{d} y)$ was associated with a prolonged improvement of asthma control in at least $33 \%$ of asthmatics receiving platcebo for one year after hatving received budesonide 1200 $\mu \mathrm{g} /$ day for two years in a double-blind study. These data are thus in favour of prolonged treatment.

Would half the dose of inhaled steroids be as effective in maintaining such atcontrol of asthmat? There are no published studics that have addressed this question. However, in at 
double-blind placebo controlled study, doubling the effective dose of inhaled steroids was associated with improvement in symptoms, diminution in rescue bronchodilators and improvement in bronchial responsiveness; however, this tendency for improvement was not statistically significant (22).

It is therefore justified to give initially the maximal low dose of inhaled steroids judged to be safe (ie, 400 to 500 $\mu \mathrm{g} /$ day of budesonide or beclomethasone) to any asthmatic with daily symptoms. Once the treatment is started and shown to be cflicicious, it should be continued for a minimum of one ycar; then, possibly, attempts should be made to try to reduce the dose of medication slowly or even stop it, but not hesitating to increase the dose if needed.

\section{INHALED STEROIDS VERSUS OTHER ANTI-INFLAMMATORY DRUGS}

Sodium cromoglycate and nedocromil sodium are alternatives to inhaled steroids as first line treatment of adult asthma. However, whereas cromoglycate is effective in improving the control of asthma in adults (23), the improvement is clearly inferior to low dose inhaled steroids. Bel et al (17) showed that nedocromil $4 \mathrm{mg}$ qid was as effective as beclomethasone $100 \mu \mathrm{g}$ qid in asthmatics in terms of symptom improvement, reduction in use of beta2-agonists and decrease in bronchial responsiveness, but the improvement in forced expiratory volume in $1 \mathrm{~s}\left(\mathrm{FEV}_{1}\right)$ was superior with beclomethasone. However, to obtain effective control of asthma, nedocromil must be taken on a qid basis, while the same degree of control can be obtained with one inhalation twice a day of the concentrated formulations of beclomethasone or budesonide.

This clearly favours the use of inhaled steroids for improv-

\section{REFERENCES}

Hargreave FE, Dolovich J. Newhouse MT. The assessment and treatment of asthma: a conference report. J Allergy Clin Immunol 1990;85:1098-1 I I.

3. Malo JL, Boulet LP, Cartier A, Hargreave FE, Dolovich J, Newhouse MT. Evaluation et traitement de l'asthme: compte rendu d'une conférence. Le Clinicien 1990;(Suppl):4-22.

$\therefore$ Guidelines on the management of asthma. Statement by the British Thoracis Society, the British Pediatric Association, the Research Unit of the Royal College of Physicians of London, the King's Fund Centre, the National Asthma Campaign, the Royal College of General Practitioners, the General Practirioners in Asthma Group, the British Association of Accident and Emergency Medicine, and the British Paediatric Respiratory Group. Thorax 1993:48:Si-24.

4. International consensus report on diagnosis and treatment of asthma. Clin Exp Allergy 1992;22(Suppl 1): 1-72.

5. Guidelines for the diagnosis and management of asthma. National Heart, Lung, and Blood Institute. National Asthma Education Program. Expert Panel Report. J Allergy Clin Immunol 199I;88:425-534.

6. Toogood J. Complications of topical steroid therapy for asthma. Am Rev Respir Dis 1990; 141:S89-96.

7. Toogood J, Baskerville J, Jennings B. Lefcoe N, Johansson SA, Use of spacers to facilitate inhaled corticosteroid treatment of asthma. Am Rev Respir Dis 1984;129:723-9.

8. Wong J, Black P. Acute adrenal insufficiency associated with high dose inhaled steroids. BMJ 1992:304:14I5

y. Brown PH, Greening AP. Crompton GK. Large volume spacer devices and the influence of high dose beclomethasone dipropionate on hypothalanopituitary-adrenal axis function. Thorax 1993:48:233-8.

10. Selroos O, Halme M. Effect of volumatic spacer and mouth rinsing on systemic absorption of inhaled corticosteroids from a metered dose inhaler and dry powder inhaler. Thorax 1991:46:891-4.

11. Toogood JH, Markov AE, Baskerville J. Dyson C. Association of ocular cataracts with inhaled and oral steroid therapy during long-term treatment of asthma. J Allergy Clin Immunol 1993:91:571-9.

12. Capewell S, Reynolds S. Shuttleworth D. Edwards C. Finlay AY. Purpura and dermal thinning associated with high dose inhaled corlicosteroids. BMJ 1990;300:1548-51. ing patient compliance. Indeed, nedocromil $4 \mathrm{mg}$ bid is less effective than $4 \mathrm{mg}$ qid and no studies have been done with nedocromil $8 \mathrm{mg}$ bid.

\section{CONCLUSION}

Although inhaled steroids are used as a first line treatment in asthma, inhaled betaz-agonists are still the first choice to relieve symptoms, and every asthmatic should have a beta2agonist inhaler at hand for treating asthma symptoms. However, when a mild asthmatic subject requires a betaz-agonist regularly and almost daily, he or she should receive at least a trial of low dose inhaled steroids at the equivalent dose of 400 to $500 \mu \mathrm{g} /$ day of budesonide or beclomethasone. The triat should last for at least four weeks and, if there is no improve ment in symptoms or reduction in beta2-agonist use, the steroids should be stopped. There are no studies that have examined the prophylactic use of steroids in this situation. whereas Juniper et al (13) have shown that in patients in whom asthma control was improved there is a clear reduction in asthma exacerbations with the prophylactic use of inhaled steroids. On the other hand, if the administration of low dose inhaled steroids is associated with a significant improvement in symptoms, and even if there is almost no use of beta2agonist, it is justified to continue the inhaled steroids at the same dose in order to maximize the gain. The duration of treatment should be at least one year after which one may try to reduce the dose to one inhalation per day for five or six months, trying then to stop it, without hesitating to increase or reintroduce the steroid upon recurrence of symptoms.

In conclusion, the early use of low dose inhaled steroids as a first line treatment will improve the quality of life of asthmatics, the majority having only mild symptoms (24).

13. Juniper EF, Kline PA. Vanzieleghem MA, Ramsdale EH, O'Byrne PM, Hargreave FE. Effect of long-term treatment with an inhaled corticosteroid (budesonide) on airway hyperresponsiveness and clinical asthma in nonsteroid-dependent asthmatics. Am Rev Respir Dis I990:142:832-6.

17. Haahtela $T$, Jarvinen M, Kava T, et al. Comparison of a beta 2-agonist, terbutaline, with an inhaled corticosteroid, budesonide, in newly detected asthma. N Engl J Med 1991;325:388-92

15. Agertoft L, Pedersen S. Effects of long-term treatment with an inhaled corticosteroid on growth and pulmonary function in asthmatic children. Respir Med 1994;88:373-8I.

16. Haahtela T, Jarvinen M, Kava T, ef al. Effects of reducing or discontinuing inhaled budesonide in patients with mild asthma. N EngI I Med 1994:331:700-5

17. Bel EH, Timmers MC, Hermans J, Dijkman JH, Sterk PJ. The long-term effects of nedocromil sodium and beclomethasone dipropionate on bronchial responsiveness to methocholine in nonatopic asthmatic subjects. Am Rev Respir Dis 1990;141:21-8.

18. Kraan J, Koeter GH, van der Mark TW, et al. Dosage and time effects of inhaled budesonide on bronchial hyperreactivity. Am Rev Respir Dis 1988:137:44-8.

I9. Jenkins CR, Woolcock AJ. Effect of prednisone and beclomethasone dipropionate on airway responsiveness in asthma: a comparative study. Thorax 1988;43:378-84

21. Juniper EF. Kline PA, Vanzieleghem MA, Hargreave FE. Reduction of budesonide after a year of increased use: a randomized controlled trial to evaluate whether improvements in airway responsiveness and clinical asthma are maintained. J Allergy Clin Immunol 1991:87:483-9.

21. Osterman K. Carlholm M, Erlandsson G, et al. Long-term treatment with inhaled budesonide (dry powder) $400 \mathrm{~g}$ daily in newly detected asthma. Eur Respir J 1993;6(Suppl 17):119S. (Abst)

22. Juniper EF, Kline PA, Vanzieleghem MA, Ramsdale EH. O'Byrne PM. Hargreave FE. Long-term effects of budesonide on airway responsiveness and clinical asthma severity in inhaled steroid-dependent asthmatics. Eur Respir J 1990:3:1122-7.

2.. Petly TL. Rollins DR, Christopher K. Good JT. Oakley R. Cromolyn sodium is effective in adult chronic asthmatics. Am Rev Respir Dis 1989:139:694-701.

24. Boston Consulting Group. Les Coûts de l'Asthme Chez l'Adulte au Canada. Mississauga: Glaxo Canada Inc, 1993. 


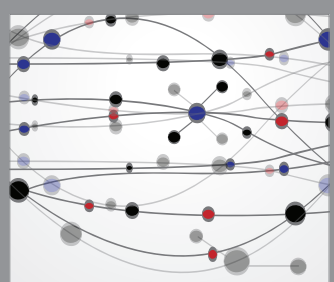

The Scientific World Journal
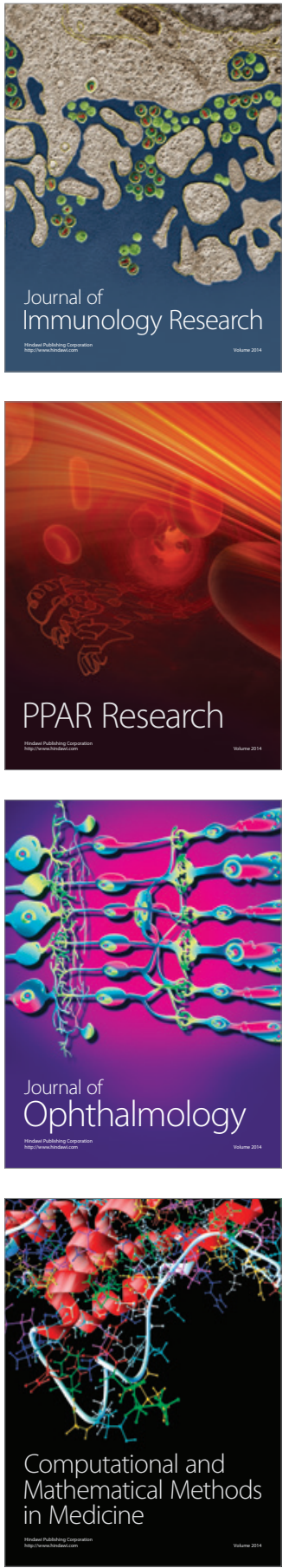

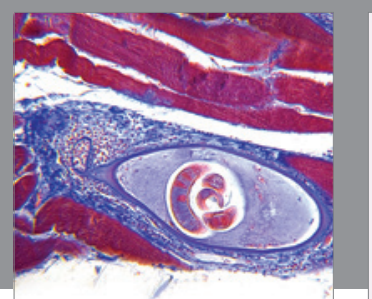

Gastroenterology Research and Practice

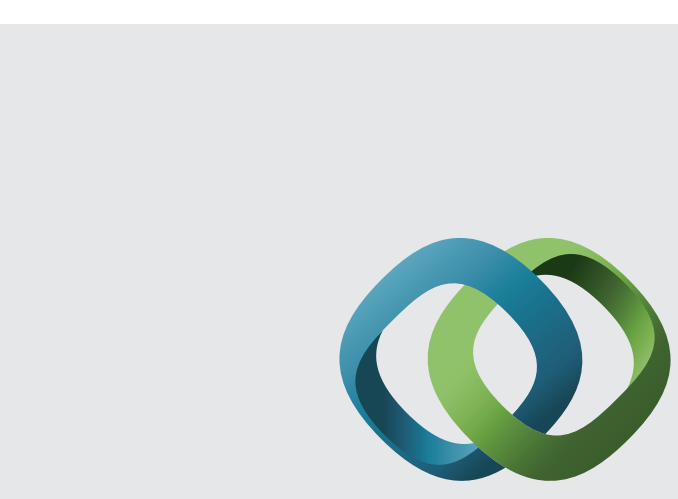

\section{Hindawi}

Submit your manuscripts at

http://www.hindawi.com
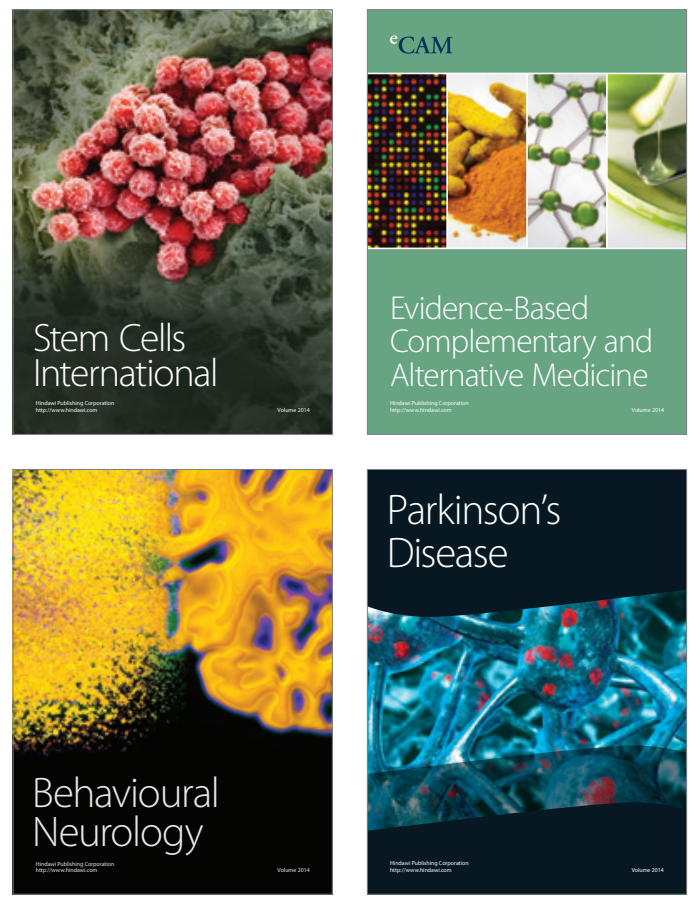
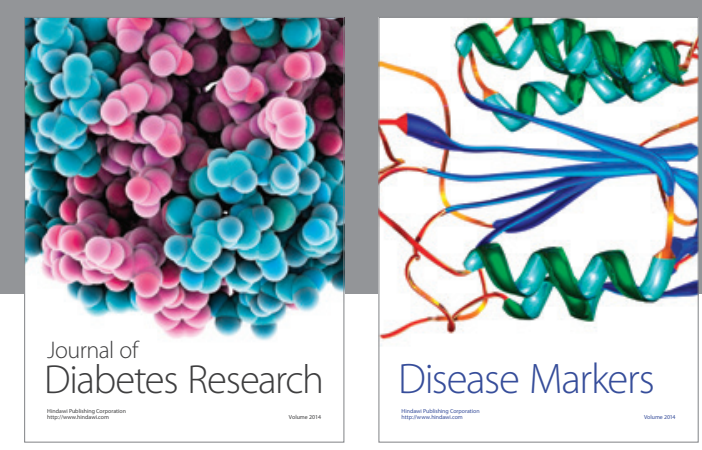

Disease Markers
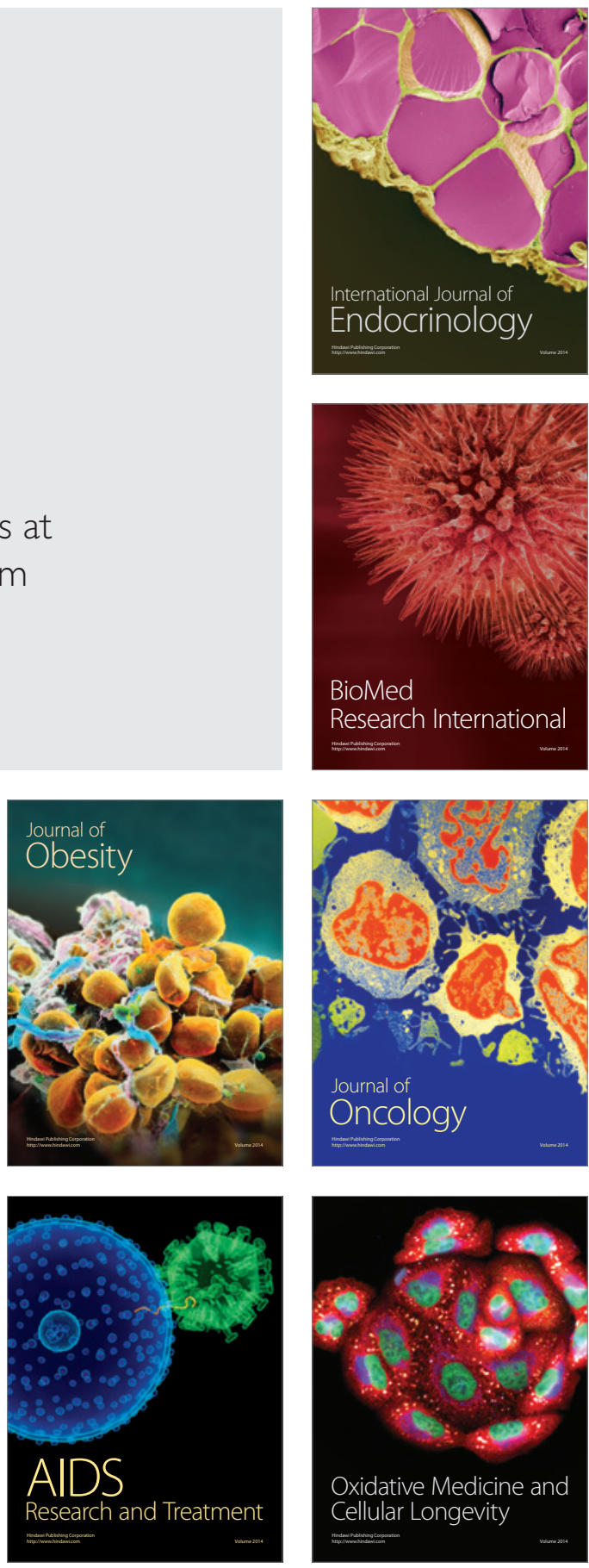